\begin{tabular}{|c|c|}
\hline \multirow{3}{*}{ 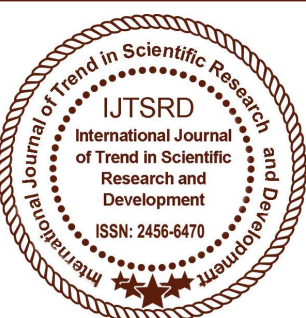 } & $\begin{array}{l}\text { International Journal of Trend in Scientific } \\
\text { Research and Development (IJTSRD) }\end{array}$ \\
\hline & Access Journal \\
\hline & ISSN No: 2456 - 6470 | www.ijtsrd.com | Volume - 2 | Issue -3 \\
\hline
\end{tabular}

\title{
A Search for Identity in Margaret Laurence's A Jest of God
}

\author{
V. Sangeetha \\ Assistant Professor, Department of English \\ Nadar Saraswathi College of Arts and Science, \\ Vadaputhupathi, Theni, Tamilnadu, India
}

\author{
B. Suganthi \\ MA English, \\ Nadar Saraswathi College of Arts and Science, \\ Vadaputhupathi, Theni, Tamilnadu, India
}

\section{ABSTRACT}

Margaret Laurence is a prolific and distinguished novelist hailing from Canada; she focuses on the fixes of women and efforts to give an individuality to the Canadian women. The theme of resolution resides a essential place in the novels of Margaret Laurence who hails from Scots-Irish circumstantial of firm standards and hard work and Puritanism. In her Manawaka novels, Laurence has given us unforgettable portraits of women wrestling with their private demons, striving through introspection to find meaningful patterns, in their lives. A jest of god is one of the Manawaka novels. The story of woman's life is not radically different from traditional patterns. Rachel suffer a lot because of problems of women and the identity in society.

\section{INTRODUCTION}

Feminism refers to a diverse variety of beliefs, ideas, movements, and agendas for action. The standard and most rudimentary explanation of feminism is that it is the confidence that women should be equal to men and presently are not. It also discusses to any movements, specially prearranged, that promote changes to society to end patterns which disadvantage or women. Feminism addresses financial, social, political and cultural differences of power and rights. The term feminism can be used to describe a political, cultural or economic movement aimed at founding equal rights and legal guard for women. Feminism involves political and sociological theories and philosophies worried with issues of gender variance, as well as a movement that advocates gender equality for women and campaigns for women's rights and welfares. The comprehensive idea of feminism refers to the belief that men and women merit parity in all occasions, treatment, respect, and social rights. In broad, feminists are people who try to admit social disparity based on gender and stop it from unending. Feminists point out that in most cultures during history men have conventional more occasions than women.

"A feminist is anyone who recognizes the equality and full humanity of women and men."

- Gloria Steinem
A SEARCH FOR INDENTITY IN "A JEST OF $G O D^{\prime \prime}$

The search for identity is the basis of the feminist drive and so it has arose as a major anxiety not only in the normal of Canadian Literature but also in the demoted literature in Canada. Another feature of Canadian feminism is the search for roots and it has arose as an superseding anxiety in much of postcolonial writing. Just like the nations having postcolonial history, the women in the Canadian milieu are doubly colonized. They have to establish themselves in their own communities as well as to the 'other' Canadians, especially those who have more planetary, more say in the montage of cultures. The most noticeable characters of Laurence's novels are their tongue-tied nature, sometimes as a sign of 
conquest and notification and sometimes as a complaint. All through the novel "A Jest of God", Rachel is shown to be passionately repressed, kerbed to an almost irrational degree and conflicting to all exhibitions of precipitate feeling.

In her Manawaka novels, Laurence has agreed us "unforgettable portraits of women wrestling with their person demons, striving through selfexamination to find meaningful patterns in their lives." Rachel Cameron, the protagonist in "A Jest of God," had been in Laurence's mind for numerous years before she actually wrote her story. In an interview, Margaret Laurence has said: "I don't think I have ever written anything in which the main character hasn't been in my mind for at least several years." Consequently, characters like Rachel remain indelibly fixed in the minds of the readers.

In the beginning, Rachel thinks that Grace Doherty does not deserve to be James' mother. She feels that Grace is not bringing up the child in a proper manner. Grace is concerned about James getting a good report only because she does not want James to do worse than her sister - in - law's boy. It is only when Rachel talks to Grace about James' truant behaviour in the school that she moves over to Grace's side. Grace admits that sometimes she allows James to run around in nature instead of going to school. In fact, she was with James on both the principal's wife. Henceforth, James becomes a symbol of free spirit to Rachel.

The conservation society of Manawaka has taught Rachel to repress has feelings. That is why she wants to escape society even in her dreams. When she dreams her lover entering her, the locale is either a forest or a beach because "it has to be right away from everywhere. Otherwise she may be seen." (18) In one of her dreams, Rachel finds herself in a gaudy Hollywood orgy in ancient Egypt. In real life, when she surrenders to Nick, the two are outside the town. There are no comfortable beds around-Nick enters her on the ground.

Rachel rebels against restrictions of her parents and starts a long search for the source of power inside of herself. Her affair with her childhood friend Nick Kazlik becomes a new experience to Rachel. This short relationship becomes a meaningful event for Rachel's transformation. Their connection becomes not a simple love affair. There are many things which unite them. Lack of communication becomes a serious obstacle in their relations. Despite communication with Nick is extremely difficult for Rachel he becomes that person who awakes her emotions and fantasies. Nick also tries to deal with his fears. Nick and Rachel reflect each other and despite their relations end soon they help Rachel to reach in important point on her path of personal transformation. This short affair gives Rachel new vision of herself, discovers her sexuality and helps her to rebel against strict norms of her mother. Despite she experiences a lot of fear, pain and offence because of this relationship it sill becomes an important step to independence and freedom. The novel gives a deep insight into the inner world of the protagonist.

Margaret Laurence creates a real character who has to deal with real problems and restrictions. In A Jest of God, Rachel is disadvantaged of a fulfilling lifestyle mainly because of the bounds she is placed under by her mother. Day in, and day out, Rachel is living a limited life and feels there is no opportunity of changing it.

Further, Calla's hyacinth is "in bud and just about to give birth"; the same might be said of Calla's desire for Rachel which, a few nights later, bursts into full bloom after the incident in the Tabernacle. And finally, Calla discards her name: to reject one's name is to reject one's identity--or, in Calla's case, to reject an identity compulsory upon her from without. She rejects those aspects of female identity which society executes on women, with conformist "femininity," heterosexuality, wifehood, and motherhood. Her refusal of the white lily, a symbol of death, accentuates the contrast between herself and Rachel, who lives her death-in-life being above a funeral chapel. Then, of course, there is Calla's religious identity: the church of the Manawaken establishment is Presbyterian, and Calla rejects it. Her story ends with her taking leave of Manawaka as she and her mother set out for Vancouver. Nothing much has improved on the seeming of Rachel's life and yet hers is a story of restoration within borders, "I will be different. I will remain the same" (201). It is still a world of flowing symbols where the lot is both true and false. But Rachel has come to accept her limits of compassionate and has found a voice which gaily admits her self-divisions "Sometimes I will feel lighthearted, sometimes light-headed. I may sing aloud, even in the dark. I will ask myself if I am going mad but if I do, I won't know it" (202). Her prime to leave Manawaka against her mother's wishes entitles that she has at last had an self for herself. 


\section{CONCLUSION:}

Towards the end, Rachel does make a choice. Her choice to move away Manawaka designates that she is an authentic separate, trying to make her own identity. She proves herself capable of freedom. She does not achieve passionate flight and social independence; instead she is free to accept the care of her mother and to move westward into a quiet new life. Rachel Cameron does in Laurence's A Jest of God She regains her identity. In this novel, Margaret Laurence writes with grace, power, and deep sympathy about Rachel Cameron, a woman fraught to come to terms with love, with death, with herself and her world. Rachel longs for love, and contact with another human being who shares her disobedient life-force. Through her affair with Nick Kaazlik, a schoolmate from earlier years, she learns at last to reach out to another person and to make herself destitute.

\section{BIBILOGRAPHY:}

\section{Pandey Sudhakar "Perspective Ion Canadian} Fiction" New Delhi: Prestige Books - Publisher, 1994

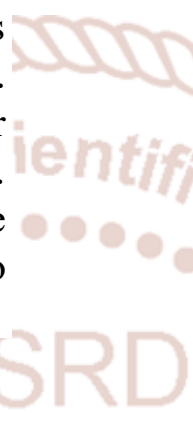
Laurence, Margaret. A Jest of God. Chicago: U of Chicago Press, 1966.Print. 